\title{
Colonialism in the Anthropocene: the political ecology of the money-energy- technology complex
}

\author{
Alf Hornborg* \\ Professor of Human Ecology, Lund University, Sweden
}

This article sketches a transdisciplinary theoretical framework for understanding the socalled Anthropocene in terms of global inequalities. The concept of the Anthropocene has several profound implications that challenge central aspects of the modern worldview. Its relation to issues of global justice requires a cataclysmic reconceptualization of conventional notions of development, economic growth, and technological progress. The article refers to the asymmetric global flows of resources that were a prerequisite to the British Industrial Revolution to illustrate how technological systems and so-called energy transitions are not just politically innocent revelations of nature, but thoroughly societal strategies of appropriation. Contemporary observations regarding environmental justice, climate justice, and energy justice can be theorized in terms of the modern inclination to think of the economy as detached from nature, and of technology as detached from world society.

Keywords: modern worldview, global inequalities, technology, Industrial Revolution, environmental justice, climate justice, energy justice

\section{INTRODUCTION}

Since its first public appearance in the year $2000,{ }^{1}$ the notion of the Anthropocene has prompted extensive deliberations about human-environmental relations across the social and natural sciences. At the time of writing this, ${ }^{2}$ a Google search on 'Anthropocene' returned 1,570,000 hits. The concept has provoked attempts at renegotiating fundamental components of the mainstream worldviews that have dominated wealthier nations in the nineteenth and twentieth centuries. In this article I shall try to identify the main challenges that the Anthropocene poses to traditional perspectives on history, progress, justice, society, and nature.

The identification of human imprints in geological sediments confirms a longstanding conviction among students of the history of human-environmental relations. As fields such as environmental history and environmental philosophy have amply documented, the insight that human activity tends to transform the non-human environment can be traced to the earliest civilizations. The modern environmental movement, often dated to the publication of Rachel Carson's Silent Spring in 1962, can

* This text overlaps with Chapter 3 in my forthcoming book Nature, Society and Justice in the Anthropocene (Cambridge University Press, Cambridge 2019)

1. PJ Crutzen and EF Stoermer, "The "Anthropocene"" (2000) 41 IGBP Newsletter 17-18.

2. 16 February 2017. 
be understood as a popular expansion and political amplification of an ancient concern about human impacts on the rest of the biosphere. Such concerns are as old as the impacts themselves, but the expanse, intensity, and ontological framing of such concerns have varied between historical periods and sociocultural contexts. Distinct varieties of environmental concern can be identified, for instance in ancient Mesopotamia, classical Rome, medieval Europe, early industrial Britain, and twentieth-century North America. Although never hegemonic in the sense of fundamentally constraining the operation of human economies and resource use, such positions have nevertheless all shared the recurrent apprehension that there is something ominous about anthropogenic environmental change. The contemporary intensification and increasing political and broader social acceptance of environmental arguments thus draw on a long tradition.

In what sense does the concept of the Anthropocene constitute a discontinuity in relation to all such earlier concerns with human impacts on the environment? In establishing an objective index with which to identify such impacts, the Anthropocene provides tangible scientific confirmation of the concerns of environmentalists. In suggesting that human activity is comparable to other factors legible in the geological record, the concept challenges the traditional conviction that such activity, although the source of obvious and deplorable ecological consequences, was ultimately too insignificant to rival the forces of Nature itself. The arrival of the Anthropocene thus seemed to dissolve the conventional ontological boundary between Society and Nature. On the other hand, the concept implies that the human species was not just one life-form among others, but a very special species capable of transforming planetary biogeochemistry and possibly of jeopardizing the integrity of the Earth system. Precisely this paradoxical conclusion, however, simultaneously provoked debate on whether the biogeochemical changes of the Anthropocene should be attributed to the agency of the human species as an undifferentiated whole, or to the operation of a specific economic system promoted by a global minority. ${ }^{3}$ In sum, the discourse on the Anthropocene has (1) strengthened environmental arguments, (2) challenged the conventional distinction between Society and Nature, (3) suggested that humans are a unique form of life, and (4) intensified the debate on climate justice.

These four implications have generated distinct genres of discourse within different fields. The first has legitimized public environmental concerns in general, and concerns about climate change in particular. It has underscored the political acceptance of concepts such as 'sustainability' and official apprehensions about transcending 'planetary boundaries'. The second has encouraged many scholars in the humanities and social sciences to adopt the so-called post-humanist conviction that the categories 'society' and 'nature' are obsolete, and that approaches suggesting 'human exceptionalism' should be rejected. The third has stimulated deliberations on precisely which uniquely human features have propelled the kinds of activities that are transforming the Earth system, for instance the capacity for symbolism, the use of money, or the proclivity for combustion. The fourth implication, finally, has prompted many scholars and politicians to highlight the relation between environmental change and inequality, which ultimately evokes the issue of human rights.

In this article, my main concern is the fourth of these issues. How should we reconceptualize the relation between human social organization and global ecology? In attempting to respond to this question, however, I will inevitably address issues raised by the first three implications listed above.

3. A Malm and A Hornborg, 'The Geology of Mankind? A Critique of the Anthropocene Narrative' (2014) 1 The Anthropocene Review 62-9. 


\section{WHAT DOES IT MEAN TO SAY THAT TECHNOLOGIES ARE SOCIAL CONSTRUCTIONS?}

To reconceptualize the relation between social organization and ecology is to rethink the relation between Society and Nature. As Bruno Latour ${ }^{4}$ and others have argued, modern worldviews have suffered from a misleading dualism that distinguishes between society and nature as ontologically separate domains. Such dualism has constrained our capacity to recognize the mutual interpenetration of the social and the natural in tangible physical phenomena such as landscapes, bodies, and technologies. Today few would deny that landscapes, bodies, and technologies all have aspects that derive from both society and nature. In order to recognize this hybridity, however, it is crucial to retain the analytical categories of society and nature. To abandon conventional patterns of thought assuming the distinctness of the social and the natural, in other words, should not mean jettisoning the concepts themselves. The posthumanists generally disregard this important difference between ontological dualism and analytical distinction. ${ }^{5}$

Our tendency to think of society and nature as domains that are insulated from each other has constrained our capacity to perceive social inequalities. As I shall show, economists tend to disregard the role of nature in accounting for social processes, while engineers tend to disregard the role of global society in accounting for the physical accomplishments of modern technology. Paradoxically, however, the posthumanist urge to jettison the categories 'social' and 'natural' also obscures social inequalities of power and distribution. The intermediate position advocated here is to recognize that the human reorganization of nature tends to be a way of physically establishing social inequalities. Much of what we conventionally perceive as nature thus has a strong social aspect, while society to a great extent builds on incontrovertibly natural phenomena. This, however, is not to downplay the importance of analytically distinguishing between those aspects of a process or object that derive from nature and those that derive from society.

This abstract argument can again be illustrated by landscapes, bodies, and technologies. Environmental historians know that domesticated landscapes everywhere reflect a social order: the layout of fields, buildings, roads, and so forth, mirror the organization of society. Anthropologists are similarly aware that human bodies everywhere reflect their positions in society: their occupation, diet, health, and so on. In neither case would it be reasonable to deny that there is also a natural substratum, whether ecological or genetic.

As we turn to the third illustration - technologies - we arrive at the central problem in rethinking the relation between society and nature. In utilizing physical regularities such as the principles of thermodynamics, technologies obviously have natural aspects, but what exactly do we include in the common observation that they are also social phenomena? It is obvious that technologies not only reflect their social contexts, performing specific functions that are in demand in those contexts, but conversely also mediate and organize social relations. Technologies may locally replace, reorganize, and control labour, increase rates of profit, serve as tools of military conquest, and generally shape human mentalities and perceptions of reality.

4. B Latour, We Have Never Been Modern (Harvard University Press, Cambridge, MA 1993).

5. A Hornborg, 'Artifacts have Consequences, Not Agency: Toward a Critical Theory of Global Environmental History’ (2017) 20(1) European Journal of Social Theory 95-110. 
Such observations permeate studies of the history of technology, whether conducted within the traditions of constructivism, ${ }^{6}$ Science and Technology Studies, ${ }^{7}$ Marxism, phenomenology, or other contributions to the philosophy of technology. However, none of these approaches fully acknowledges the extent to which technologies may presuppose and embody specific patterns of social organization at the global level. They tend to focus on the specific designs and local human consequences of given technological systems, but do not theorize their global societal prerequisites in terms of particular rates of exchange (that is, prices) on the world market.

In the category 'social', it should be emphasized, I include the organization of the entire world-system, rather than restricting the concept of society to describe a national or local phenomenon. It is clear that a given machine utilized in a production process represents a net input of physical resources, and that its output of commodities on the market must fetch exchange values in excess of those of the inputs of resources required to keep it running. Building on Nicholas Georgescu-Roegen's insight that economic processes enhancing utility simultaneously increase entropy, ${ }^{8}$ I have inferred that exchange values and productive potential must be inversely correlated, and that the accumulation of technological infrastructure therefore signifies the joint operation of thermodynamics and imperialism. ${ }^{9}$ The principles of thermodynamics clearly derive from nature, while the strategies of imperialism derive from society. However, mainstream economists are convinced that their accounts of growth and technological progress have no use for thermodynamics. In their worldview, nature is irrelevant for the constitution of society.

Whereas earlier efforts to theorize the social contexts and consequences of technology tended to relate a given technological artefact to a restricted range of immediate users, the approach advocated here is to view its very existence as contingent on global social relations of exchange. An example that I have often referred to is the steam engine employed in British textile factories in the early nineteenth century. ${ }^{10}$ It owed its existence not only to the ingenuity of inventors like James Watt, but fundamentally also to the lucrative structures of exchange between Britain, West Africa, and America. Without the trans-Atlantic flows of embodied African labour and embodied American land, and the African and American markets for British textiles, it is difficult to imagine a British Industrial Revolution. At the global level, technologies are indeed infused with social organization in a sense unacknowledged by earlier schools of thought. Whereas other approaches to the social dimension of technology might focus, for instance, on the local social negotiations leading to the optimally designed engine, the factory owners' use of steam engines to discipline labour, the use of steam engines as tools of British imperialism, or workers' experiences of labour in steamdriven factories, none of these approaches problematizes the ontology of technology itself. They assume the existence of an artefact like the steam engine as a product of

6. WE Bijker, TP Hughes and TJ Pinch, The Social Construction of Technological Systems (The MIT Press, Cambridge, MA 1987).

7. B Latour, Science in Action: How to Follow Scientists and Engineers through Society (Harvard University Press, Cambridge, MA 1987).

8. N Georgescu-Roegen, The Entropy Law and the Economic Process (Harvard University Press, Cambridge, MA 1971).

9. A Hornborg, 'Machine Fetishism, Value, and the Image of Unlimited Good: Toward a Thermodynamics of Imperialism' (1992) 27 Man (N.S.) 1-18.

10. A Hornborg, Global Ecology and Unequal Exchange: Fetishism in a Zero-Sum World (Routledge, London 2011). 
the strategies of engineers, capitalists, and other human actors, reflecting their purposes and imposing their designs on other people; but such approaches do not reflect on the steam engine as an embodiment of the world-system which made it possible to begin with. Nevertheless, as much as a biological organism is a literal embodiment of the biophysical flows of energy and matter which sustain it, a machine is an embodiment of biophysical resource flows, orchestrated by money and prices. Although many philosophers have emphasized that some material objects, such as living organisms, should be understood in relational terms - as manifestations of wider webs of relationships - this insight has not been extended to technological artefacts. ${ }^{11}$

\section{RETHINKING THE HISTORY OF TECHNOLOGICAL PROGRESS AS AN INDEX OF UNEQUAL EXCHANGE}

The identification of an industrial technology such as steam power with the inequitable global social system which made it possible prompts us to rethink conventional narratives of industrialization and technological progress. The British shift from wool to cotton as the dominant raw material for textile production was tantamount to a gross displacement of requirements for land from Britain to America, and the use of slave labour in the cotton plantations similarly entailed a displacement of workloads overseas. Although locally perceived as morally and politically innocent "progress', from a global perspective the Industrial Revolution instead assumes the appearance of an asymmetric exchange of embodied labour time and a massive environmental load displacement.

A common objection to this line of reasoning is that the technology 'as such' does not necessarily imply inequitable exchange relations or environmental load displacement. This was certainly the view held by Karl Marx, who predicted that the productive forces generated by capitalism could be extricated from their capitalist context and employed for collective benefit under communism. He apparently perceived technology, understood as the enhancement of the productivity of local labour through the use of resources imported from elsewhere, as innocent 'in itself'. Given more recent insights into the inextricable connections between artefacts and their social contexts, however, such a detachment of a technology from the exchange relations which spawned it now seems implausible, even from a purely social-science perspective. To imagine the steam engine as detachable from asymmetric global resource flows (whether orchestrated by the market or political coercion) reflects what I have referred to as 'machine fetishism'. Extending Marx's observations on money and commodity fetishism to the field of technology, I propose that machines, like money and commodities, are (global) social relations masquerading as things.

Drawing on thermodynamics, we must infer that the resource flows to and from industrial centers are necessarily asymmetric in a physical sense, yet we also know that this is not the way it looks to mainstream economists. The relation between

11. It is significant that relational perspectives explicitly challenge 'the famous mechanistic theory of nature with which science had broadly remained content since the seventeenth century, mainly because it worked so well across a broad terrain of technological practices' (D Harvey, Justice, Nature and the Geography of Difference (Blackwell, Oxford 1996) 257). Although the machine has long served as a model of nature, it cannot even itself be exhaustively accounted for with a mechanistic narrative. This insight should once and for all invalidate the mechanistic worldview. 
the divergent perspectives of physics and economics is central to the difficult reconceptualization of technology that I am proposing. It is incontrovertible that there was a massive net transfer of biophysical resources to Britain in the 1870 s, yet the science of economics at this time established an approach to human economies that effectively disregarded the physical substance of traded commodities. The school of neoclassical economics, which achieved dominance in Britain in the 1870s, is exclusively concerned with exchange values ('utility') and flows of money. Its preoccupation with market mechanisms of supply and demand made the colonial appropriation of embodied labour, land, energy, and materials invisible. The growth of technological infrastructure in Britain could thus be interpreted as the laudable product of 'free' trade, rather than as the accumulation of resources from the colonies in the core of the empire. The challenge for British industry was to secure advantageous price relations on the world market. This could generally be achieved through various combinations of economic, political, and military means, but in focusing on and objectifying the notion of 'prices', the worldview promulgated by neoclassical economics could deny that the accumulation of technology presupposes unequal exchange. In other words, the new framing of asymmetric exchange - as the 'free' and morally neutral operation of market trade - enabled global structures of resource appropriation to survive the official end of colonialism. Neoclassical economic theory is an ideology originally developed in colonial Britain to justify and morally neutralize the exploitation of its extractive periphery. ${ }^{12}$ In its modern, neoliberal guise, it has championed 'globalization' as a modern euphemism for imperialism.

We evidently need to take a closer look at the concept of 'unequal exchange'. It has been used by theorists of imperialism and world-systems to denote a transfer of 'surplus value' from less to more affluent economies. In an argument couched in the Marxist labour theory of value, Arghiri Emmanuel demonstrated that differences in the price of labour (i.e. wages) between nations will generate net transfers of embodied labour in international trade. ${ }^{13}$ Immanuel Wallerstein is generally less explicit in his use of the concept of 'unequal exchange', but also draws on Marxist theory and appears to denote a transfer of 'surplus value' defined in terms of invested labour time. ${ }^{14}$

The sociologist Stephen Bunker pioneered a definition of unequal exchange that transcends the labour theory of value. ${ }^{15}$ His approach to development theory is highly inspired by structuralism, dependency and world-system perspectives, but is critical of their emphasis on labour value. Using the history of the Amazon Basin as a case study, he instead suggests that the polarization of core versus peripheral sectors is the result of an unequal exchange of 'energy values' extracted from nature and transferred to centers of accumulation. As his contribution is pivotal for the subsequent conceptualization of ecologically unequal exchange, we shall consider it in some detail.

12. For a discussion of how different schools of economic thought have served to justify different historical injustices, see V Ruggiero, The Crimes of the Economy: A Criminological Analysis of Economic Thought (Routledge, London 2013).

13. A Emmanuel, Unequal Exchange: A Study of the Imperialism of Trade (Monthly Review Press, New York, NY 1972).

14. I Wallerstein, The Modern World-System (Academic Press, San Diego, CA 1974-1989) $1-3$.

15. SG Bunker, Underdeveloping the Amazon: Extraction, Unequal Exchange, and the Failure of the Modern State (The University of Chicago Press, Chicago, IL 1985). 
Bunker asserts that 'the Amazon's major export economies have been based on extraction of value from nature rather than on the creation of value by labor', and that 'the differences between extractive and productive economies [are] more fully accounted for by the laws of thermodynamics than by theories of politically enforced unequal exchange'. ${ }^{16} \mathrm{He}$ states that 'the exploitation of natural resources uses and destroys values in energy and material which cannot be calculated in terms of labor or capital'. ${ }^{17}$ Importantly, he notes that theories of imperialism, world-systems, dependency, and 'unequal exchange based on wage or productivity differentials ... have all acknowledged primary material export as a defining characteristic of most forms of underdevelopment, but they have not systematically explored the internal dynamics of extractive systems' as a consequence of energy flows. ${ }^{18}$ Because dependency and world-system perspectives 'draw too much on labor theories of value', he asserts, 'they cannot account for the multiple effects of unbalanced energy flows between different regions. ... Any theory of international exchange which measures commodity flows between regions only in terms of capital, prices, or the labor incorporated into each is therefore ... wrong'. ${ }^{19}$

Bunker's interpretation of the problem is that 'nature, values in nature, and the economies which depend on values in nature have been systematically undervalued' ${ }^{20}$ He proposes that if we widen Emmanuel's concept of unequal exchange, 'then we can say that countries where labor values and natural values are seriously undercompensated will tend indeed to be underdeveloped'. He concludes, 'the need is to slow the flow of energy to the world center', primarily 'by raising the relative monetary costs of extracted commodities and thus slowing their consumption in the core'. ${ }^{21}$

When I published my argument on 'the thermodynamics of imperialism' in 1992 I had not yet discovered Bunker's work, but I similarly believed that 'value' should be redefined in terms of energy. ${ }^{22}$ However, when I later proposed an 'ecological theory of unequal exchange', I emphasized that energy and values should not be confused, explicitly disagreeing with this aspect of Bunker's analysis. ${ }^{23}$ The issue is pivotal to rigorously theorizing ecologically unequal exchange. No doubt influenced by the fundamental Marxian notion that monetary exchange values conceal asymmetric flows of 'use values', heterodox economists tend to be intent on defining an objective, insufficiently compensated measure of economic value, rather than simply observing that flows of money represent the asymmetric exchanges of biophysical resources on the world market as if they were reciprocal. The misleading argument on asymmetric transfers of underpaid 'values' recurs not only in Marxian attempts to conceptualize

16. Ibid 12.

17. Ibid 22 .

18. Ibid 30.

19. Ibid 245-6.

20. Ibid 31 .

21. Ibid 252-3.

22. Or rather 'exergy' (the energy available for harnessing for work). Hornborg (n 9); the same analytical flaw recurs in A Hornborg, 'Ecosystems and World Systems: Accumulation as an Ecological Process' (1998) 4(2) Journal of World-Systems Research 169-77 at 172, reprinted in A Hornborg, The Power of the Machine: Global Inequalities of Economy, Technology and Environment (AltaMira, Walnut Creek, CA 2001) 57-9.

23. A Hornborg, 'Towards an Ecological Theory of Unequal Exchange: Articulating World System Theory and Ecological Economics' (1998) 25(1) Ecological Economics 127-36. 
ecologically unequal exchange and the appropriation of nature, ${ }^{24}$ but also in the work of some ecological economists concluding that asymmetric exchange should be expressed in terms of insufficient monetary compensation. ${ }^{25}$

The analytical convergence of labour and energy theories of value is not coincidental. ${ }^{26}$ Their common source appears to be our adherence, ever since Marx, to an essentialist conception of monetary value, that is the belief that exchange values have (or should have) an analytically specifiable relation to some objective, material substratum of reality. Paradoxically, however, a coherent theory of ecologically unequal exchange must simultaneously emphasize the economic relevance of biophysical parameters for human economies and disconnect them from notions of economic value. The significance of asymmetric transfers of material resources is not that they represent underpaid values, but that they contribute to the physical expansion of productive infrastructure at the receiving end. The accumulation of such technological infrastructure may yield an expanding output of economic value, but this is not equivalent to saying that the resources that are embodied in infrastructure have an objective value that exceeds their price. The unequal or asymmetric exchanges on the world market that need to be acknowledged are exchanges of biophysical resources, not 'values'. ${ }^{27}$ If our conclusion were to be that the problem is that 'natural values' are underpaid or even unpaid, our analysis would not probe deeper than the claims of mainstream economists that environmental 'externalities' (such as 'ecosystem services') are insufficiently reflected in market prices. In short, we need to liberate our analyses from the conceptual constraints of money. Monetary value is not an essence but a cultural veil obscuring material asymmetries by representing unequal exchange as reciprocal. Money cannot compensate for entropy.

This is not to say that it is illegitimate of victims of environmental injustice to demand monetary indemnification, such as is exemplified by the notion of an 'ecological debt' owed by wealthier nations to less developed ones, ${ }^{28}$ but only to remind

24. JB Foster and H Holleman, 'The Theory of Unequal Ecological Exchange: A Marx-Odum Dialectic' (2014) 41(2) The Journal of Peasant Studies 199-233; JW Moore, Capitalism in the Web of Life: Ecology and the Accumulation of Capital (Verso, London 2015).

25. HT Odum and JE Arding, EMERGY Analysis of Shrimp Mariculture in Ecuador (University of Rhode Island, Narragansett 1991); HT Odum, Environmental Accounting: EMERGY and Environmental Decision Making (John Wiley \& Sons, New York 1996; J Martinez-Alier, The Environmentalism of the Poor: A Study of Ecological Conflicts and Valuation (Edward Elgar Publishing, Cheltenham, UK and Northampton, MA, USA 2002). In fairness to Martinez-Alier, however, it should be added that he clearly recognizes that the incommensurability of physical deterioration and monetary values 'makes it hard to produce a measure of ecologically unequal exchange, in the fashion that conventional economics is familiar with' (ibid 216).

26. SC Lonergan, 'Theory and Measurement of Unequal Exchange: A Comparison between a Marxist Approach and an Energy Theory of Value' (1988) 41 Ecological Modeling 127-45.

27. Although such flows of biophysical resources remain outside most economists' field of vision, it can be empirically demonstrated that core areas of the capitalist world-system (Europe, North America, and Japan) in 2007 were net importers of embodied labor, land, energy, and materials; C Dorninger and A Hornborg, 'Can EEMRIO Analyses Establish the Occurrence of Ecologically Unequal Exchange?’ (2015) 119 Ecological Economics 414-18. For additional substantiation of the theory of ecologically unequal exchange, see AK Jorgenson and B Clark (eds), Special Issue: Ecologically Unequal Exchange in Comparative Perspective (2009) 50(3-4) International Journal of Comparative Sociology; A Hornborg and J MartinezAlier (eds), Special Issue: Ecologically Unequal Exchange and Ecological Debt (2016) 23(1) Journal of Political Ecology.

28. Martinez-Alier (n 25) at 213-51. 
ourselves that money cannot neutralize ecological damage in a physical sense. Monetary compensation for environmental damage can reduce contemporary grievances, but it is illusory to believe that 'correct' reparations could be calculated, or that they would somehow set things straight. The ecological debt of Britain, for instance, is as incalculable as its debt to the descendants of West African slaves. To raise the price of energy and raw materials, as Bunker suggested, would undoubtedly reduce the current magnitude of ecologically unequal trade (and the accumulation of technological infrastructure) in the world, but it would not make trade equal. Like the notion of making 'correct' recompense for past asymmetries, pricing resources high enough to neutralize the damage caused by their extraction would be tantamount to shutting down industrial capitalism.

\section{ENVIRONMENTAL JUSTICE}

The aim of my argument so far has been to establish that the accumulation of technological infrastructure, or what is widely referred to as 'development' and 'progress', is an inherently moral and political issue. The uneven global distribution of such infrastructure is visible on satellite images of night-time lights and is closely correlated with the geographical distribution of high average gross domestic product (GDP), that is, the distribution of money. The pattern agrees well with my proposal that the phenomenon of 'modern' technology ${ }^{29}$ should be understood not simply as an index of ingenuity, but as a social strategy of appropriation (of labour and land), which is tantamount to saying that it is a strategy of displacement (of work and environmental loads). This capacity for appropriation and displacement correlates with purchasing power because it operates through money. The implication is that modern technology is inextricably connected to what Joan Martinez-Alier calls 'ecological distribution conflicts'. ${ }^{30}$ In other words, economic development and technological progress are intrinsically associated with issues of environmental justice.

Conflicts over environmental justice are a central concern of the field of political ecology. ${ }^{31}$ As Martinez-Alier shows, local victims of ecological distribution conflicts and environmental injustices all over the world have articulated myriad "valuation languages' and 'idioms of resistance' which challenge the hegemonic assessments of market efficiency. The academic field of ecological economics, on the other hand, has developed a number of incontrovertible quantitative indicators of the deleterious

29. In response to the observation that humans have always used technology (exemplified by stone age axes), I reserve the concept as used here for systems of artefacts which rely, for their existence, on a geographically dispersed division of labour, international differences in the prices of labour and other resources, world trade, and inorganic energy. Such conditions fundamentally transformed the potential for 'technological progress' in some parts of the worldsystem in the late eighteenth century. The prototypically 'modern' technology, in this sense, is the steam engine.

30. Martinez-Alier (n 25).

31. Ibid 70-74; RL Bryant and S Bailey, Third World Political Ecology (Routledge, London 1997). For recent overviews of the wider theoretical concerns and methodological approaches of political ecology, see T Perreault, G Bridge and J McCarthy (eds), The Routledge Handbook of Political Ecology (Routledge, London 2015); RL Bryant (ed), The International Handbook of Political Ecology (Edward Elgar Publishing, Cheltenham, UK and Northampton, MA, USA 2015); R Peet, P Robbins and MJ Watts (eds), Global Political Ecology (Routledge, London 2011). 
biophysical impacts of economic processes, while mainstream economists have generally remained unperturbed. Jointly, environmental activists and critical academics today provide powerful signals that the economic models born in colonial Britain were not designed to promote a sustainable and equitable planet, yet no fundamental rethinking appears to be occurring within the established discipline of economics itself. Although few would deny that current economic policies are inexorably generating rising inequalities, resource depletion, greenhouse gas emissions and financial vulnerabilities, for a respectable economist to seriously question the design of the money artefact ultimately responsible for these processes would be as unthinkable as it would have been for a fourth-century Roman to question slavery, or a fourteenthcentury Easter Islander to question deforestation. In addition to submitting to the sheer inertia of conducting business as usual, of course, the tenacity of conventional economic thought reflects the implacable interests of powerful shareholders, executives, and politicians.

The innumerable examples of environmental injustice throughout the world provide a vast range of 'case studies' in political ecology, illustrating how the tensions between corporate profit interests and the integrity of local ecosystems (including humans) generate similar kinds of confrontations and political activism. Such tensions and conflicts can be classified and theorized in a number of ways, depending on whether we focus, for instance, on the discourse of the activists, on the dynamics of the social movements, on the type of corporations, on the outcome of confrontations, or on other parameters. For many years, my aim has been to grasp and articulate, in as succinct and extensively applicable terms as possible, the common structural logic underlying such recurrent tensions between the imperatives of economics and the demands of justice and sustainability. My objective has been to distill the core concerns of political ecology and environmental justice, asking how the human reorganization of nature in various contexts has served to establish and reinforce social inequalities. These concerns have led me to pursue a more rigorous analytical framework for conceptualizing ecologically unequal exchange, which simultaneously provides a radically heterodox understanding of technology.

David Harvey also aims to reveal the underlying mechanisms that generate the wide variety of environmental justice issues. ${ }^{32}$ To pursue this aim he is compelled to review (and frequently to dismiss) a diverse range of contemporary discourses on the environment, suspecting that 'the vast conceptual muddle and cacophony of discourses is far from innocent in the reproduction of capitalism'. ${ }^{33} \mathrm{He}$ critically discusses a long and rather haphazard series of approaches to 'how human beings have valued their natural world', highlighting how unfeasible it is to reduce 'a wondrous multidimensional ecosystemic world of use values, of human desires and needs, as well as of subjective meanings, to a common objective denominator', that is, money. ${ }^{34}$ Harvey also explores the tension between the Marxist ambition to provide an abstract, universally applicable theory of commodification, exploitation, and alienation, on the one hand, and phenomenological approaches emphasizing particular, local human experiences of place, on the other. He observes that 'the increasing penetration of technological rationality, of commodification and market values, and capital accumulation into social life (or into what many writers, including Habermas, call "the life world") together with time-space compression, will provoke resistances

32. Harvey (n 11).

33. Ibid 173.

34. Ibid $150-51$. 
that increasingly focus on alternative constructions of place'. ${ }^{35}$ Struggling to safeguard his own Marxist approach at a time when universalizing 'grand narratives' were being discredited by the prevalent postmodern turn in social science, Harvey challenges 'the postmodern death of justice', that is, the widespread consensus that 'there can be no universal conception of justice to which we can appeal as a normative concept', but 'only particular, competing, fragmented, and heterogeneous conceptions of and discourses about justice which arise out of the particular situations of those involved'. 36

Harvey deplores the 'incredible vigor with which ruling interests have sought to contain, shape, mystify, and muddy the contemporary debate over nature and environment', for example "within discourses of "ecological modernization," ... "sustainability," "green consumerism," or the commodification and sale of "nature" as a cultural spectacle'. In addressing the tendency of such discourses to obscure and confuse 'the key institutional and material practices that really matter for the perpetuation of capitalist social and power relations', ${ }^{37}$ Harvey is more intent on deconstructing discourses than on identifying those deleterious and inequitable material practices themselves. Although the dense 439 pages of his book Justice, Nature and the Geography of Difference touch upon just about every other topic that might have some bearing on the relation between nature and inequality, he makes no attempt to theorize unequal exchange in terms of asymmetric transfers of physical components of nature, such as energy, materials or embodied land. This is tantalizing, as his aim is precisely to establish a universalizing approach with which to challenge the hegemony of exchange values:

The refusal to cast discussion in monetary terms ... reflects an intuitive or experiential understanding of how it is that seemingly fair market exchange always leads to the least privileged falling under the disciplinary sway of the more privileged and that costs are always visited on those who have to bow to money discipline while benefits always go to those who enjoy the personal authority conferred by wealth. There is an acute recognition within the environmental justice movement that the game is lost for the poor and marginalized as soon as any problem is cast in terms of the asymmetry of money exchange. ${ }^{38}$

\section{CLIMATE JUSTICE}

In recent years, the pursuit of a structural account of global injustices pertaining to the biophysical environment has been particularly evident with regards to climate change. The greenhouse gas emissions which are largely responsible for the biogeochemical transformations of the Anthropocene are a quintessential illustration of the increasing entropy production generated by the global technological infrastructure fuelled by fossil energy. They are thus an intrinsic aspect of what I have called 'the thermodynamics of imperialism'. The emissions have accelerated exponentially since the Industrial Revolution, and most conspicuously since the Second World War. Although the chemical composition of the atmosphere is a global phenomenon, the highly skewed distribution of emissions, their meteorological consequences and the financial and

35. Ibid 302 .

36. Ibid 341-2.

37. Ibid 174-5.

38. Ibid 388 (emphases in original). 
technological capacity to cope with such consequences clearly establish that anthropogenic climate change is as inextricably connected with issues of global justice as the distribution of the technological infrastructure which is the source of those emissions.

In a study that demonstrates such connections in convincing detail, J Timmons Roberts and Bradley C Parks explain the problems plaguing international climate policy negotiations in terms of structural inequalities between the wealthier nations of the global 'North' and the less developed nations of the 'South'. ${ }^{39}$ They find that the available statistics on trade, GDP, and carbon dioxide emissions in different countries strongly support the theory of ecologically unequal exchange, ${ }^{40}$ concluding that 'ecologically unequal exchange is ... not just a perception by angry and irrational Third World politicians, leftist scholars, and activists ...; it is an observable physical reality'. ${ }^{41}$ The authors also review evidence debunking the widespread notion that increasingly affluent economies tend to reduce their use of energy and materials, confirming instead that material-intensive production processes (and their emissions) tend to be shifted to poorer nations. ${ }^{42}$ Although parts of the authors' discussion of climate policy negotiations are marred by recurrent ambiguities regarding whether these structural inequalities are merely 'beliefs', 'worldviews', 'ideas', and 'perceptions' preventing 'negotiators from reaching a shared social understanding of fairness from which to build the ambitious cooperative agreement needed to address climate change effectively', ${ }^{43}$ or whether they are indeed 'a social reality', ${ }^{44}$ their argument as a whole is very well substantiated, coherent, and commendably interdisciplinary.

The imperative of such an interdisciplinary outlook in discussing climate justice is illustrated by the constraints of a narrowly economic approach, as expounded by John Broome. ${ }^{45}$ Assuming that the damages of climate change are 'externalities', all translatable into monetary 'costs', and that continued economic growth and investment will benefit future generations, making them 'better off than us', Broome at one point concludes that 'climate change diminishes intergenerational inequality' ${ }^{46}$

39. JT Roberts and BC Parks, A Climate of Injustice: Global Inequality, North-South Politics, and Climate Policy (The MIT Press, Cambridge, MA 2007). Roberts and Parks reiterate the suggestion of Bunker and others that the market prices of goods extracted from the South tend to be 'underpriced' or 'undervalued' (ibid 164,167), which, as we have shown, is a position that is both analytically flawed and unnecessary for the remainder of their argument.

40. Ibid 164-73.

41. Ibid 184.

42. Ibid 177, 183. The Assessment Report for the UNEP International Resource Panel emphasizes 'the need to decouple economic growth and human well-being from ever-increasing consumption of natural resources', but establishes that the current tendency is precisely opposite to this imperative, as the 'material intensity of the world economy has been increasing for the past decade' (emphasis added), and globally, 'more material per unit of GDP is now required'; H Schandl, M Fischer-Kowalski, J West, S Giljum, M Dittrich, N Eisenmenger, A Geschke, M Lieber, HP Wieland, A Schaffartzik, F Krausmann, S Gierlinger, K Hosking, M Lenzen, H Tanikawa, A Miatto and T Fishman, Global Material Flows and Resource Productivity: An Assessment Study of the UNEP International Resource Panel (United Nations Environment Programme, Paris 2016) 14-16.

43. Ibid 19, 23, 32-9.

44. Ibid 29.

45. J Broome, 'Do Not Ask for Morality' (2017), paper presented at the conference How to Think the Anthropocene, Paris November 2015.

46. Ibid 16. His solution to the problem of climate change is finally that governments should borrow more money for green investments. The currently soaring debts of most nations, and the 
The logic of neoclassical economics is indeed impeccable, as in Lawrence Summers' infamous memorandum demonstrating the enhanced 'efficiency' of shifting the most polluting industries to the poorest parts of the world, where the economic consequences of human illness would be less problematic. ${ }^{47}$ Only a discipline as insulated from biophysical reality (and morality) as economics could reach such bizarre conclusions as these, yet they simply elaborate the alienated and fetishized logic of money. The conceptual myopia of mainstream economics is intrinsically inimical to considerations of environmental and climate justice. The logic may be impeccable, but if the premises and assumptions on which it is founded are fallacious - as is the case with monetary reductionism and faith in perpetual growth - it can break down like a house of cards.

\section{ENERGY JUSTICE}

The question of energy use is an intrinsic source of the kinds of technologically mediated ecological appropriations and displacements which generate environmental injustices, clearly illustrated by the issue of climate justice. After decades of almost complete insulation from social theory, the topic of energy is currently re-entering and reshaping the social sciences. Rather than offering a physical substratum ('Nature') as a determinant of human social relations ('Society'), as was the inclination in some earlier models such as those of cultural ecology, ${ }^{48}$ several contemporary approaches explore how physical and social processes are intertwined. ${ }^{49}$

The recent discourse on 'energy justice' tends to approach 'socio-energy systems' as arrangements that inadvertently, as it were, have distributive consequences that can be analysed as injustices. ${ }^{50}$ Such unjust distributive consequences are presented as incidental, and thus their acknowledgement and examination is presented as an innovative theoretical project. An alternative perspective, based on the approach to

ensuing financial crises, do not seem to worry Broome any more than the misguided notion that the fantasies of financial institutions could alleviate the accelerating entropy production of our expanding use of energy.

47. Lawrence Summers Memo (World Bank 1991).

48. See MJ Watts, 'Now and Then: The Origins of Political Ecology and the Rebirth of Adaptation as a Form of Thought' in Perreault, Bridge and McCarthy (n 31) 19-50.

49. T Mitchell, Carbon Democracy: Political Power in the Age of Oil (Verso, London 2011); S Strauss, S Rupp and T Love (eds), Cultures of Energy: Power, Practices, Technologies (Left Coast Press, Walnut Creek, CA 2013); MT Huber, Lifeblood: Oil, Freedom, and the Forces of Capital (University of Minnesota Press, Minneapolis 2013); D Tyfield and J Urry (eds), Special Issue on Energy \& Society (2014) 31(3) Theory, Culture \& Society; A Malm, Fossil Capital: The Rise of Steam Power and the Roots of Global Warming (Verso, London 2016).

50. C Miller, 'The Ethics of Energy Transitions' (2014) Institute of Electrical and Electronics Engineers; BK Sovacool and MH Dworkin, 'Energy Justice: Conceptual Insights and Practical Applications' (2015) 142 Applied Energy 435-44; K Jenkins, D McCauley, R Heffron, H Stephan and R Rehner, 'Energy Justice: A Conceptual Review' (2016) 11 Energy Research \& Social Science 174-82. This discourse tends to assume that injustices associated with energy technologies should be approached as problems of engineering rather than social science. The stance is cognate to deliberations on the 'unintended consequences' of energy technologies; see O Andersen, Unintended Consequences of Renewable Energy: Problems to be Solved (Springer, London 2013). But what is 'intended' is an ambiguous question in relation to the underlying structural rationale of social organization. Even Ulrich Beck's influential contribution to sociology focuses on the sociological implications of increasing technological complexity, rather than on understanding such 
technology and unequal exchange presented here, is that the distributive logic of energy technologies is internal, rather than external, to the feasibility of the technologies themselves. In this view, the distributive implications of a given energy technology, in terms of appropriation and displacement, are not incidental but central to its societal rationale.

This is particularly evident in the nineteenth-century transition to fossil energy in the British textile industry, the success of which was clearly geared to the displacement of labour and land requirements to American cotton plantations. Land constraints were a significant factor in the British pursuit of 'ecological relief' during the Industrial Revolution. ${ }^{51}$ In early industrial England, land was a scarce resource used to generate work either in the form of human labour or some form of non-human energy such as draft animals, firewood, or charcoal. Modern, largely subterranean forms of nonhuman energy such as fossil fuels and nuclear power do not to the same extent compete with food production over eco-productive land as in pre-industrial times, but visions of renewable, post-carbon energy technologies such as biofuels may imply a reversion to such competition. ${ }^{52}$ Various forms of non-human energy are essential to capital accumulation, understood as economic-cum-technological growth. I have proposed that such growth is feasible only in restricted sectors of the world-system and is contingent on asymmetric transfers of biophysical resources from elsewhere, including embodied labour and land. New technologies thus represent means of displacing workloads and environmental loads to other parts of the world-system. This means that energy justice is an aspect of the much wider issue of economic justice in the world-system, closely connected to related concepts such as environmental justice and climate justice.

In focusing on energy technologies, the discourse on energy justice brings concerns with social justice closer to a global societal perspective on the ontology of modern technology. While the concept of 'socio-energy systems' ${ }^{53}$ usefully highlights that energy technologies are social phenomena, it brings us closer to understanding that

complexity as a sociological phenomenon of risk displacement; U Beck, Risk Society: Towards a New Modernity (Sage, London 1992). These approaches reproduce the conventional assumption that the physical and the technological are to be regarded as external to the social.

51. See K Pomeranz, The Great Divergence: China, Europe, and the Making of the Modern World Economy (Princeton University Press, Princeton, NJ 2000).

52. The understanding that a shift to renewable energy technologies would imply a return of land constraints - that is, that energy and space are transposable parameters - is receiving increasing attention in several disciplines; A Hornborg, 'The Fossil Interlude: Euro-American Power and the Return of the Physiocrats' in Strauss, Rupp and Love (n 49) 41-59; G Bridge, S Bouzarovski, M Bradshaw and N Eyre, 'Geographies of Energy Transition: Space, Place and the Low-carbon Economy' (2013) 53 Energy Policy 331-40; MT Huber, 'Theorizing Energy Geographies' (2015) 9(6) Geography Compass 327-38. An abstract conclusion regarding the transposability of energy and space is that, in pre-industrial societies, eco-productive space provides access to energy, while in industrial ones, fossil energy provides access to space. The analytical link between space and energy is time, as it requires vast spans of time for eco-productive space to yield fossil energy, and as it is by reducing the expenditure of time in movement (that is, increasing velocity) that fossil energy can provide access to more space. The latter point builds on the fundamental insight of Torsten Hägerstrand's 'time geography'; M Gren, 'Time Geography' in R Kitchin and $\mathrm{N}$ Thrift (eds), The International Encyclopedia of Human Geography (Elsevier, Amsterdam 2009). The time 'embodied' in fossil energy in effect saves time for the users of modern technology.

53. Miller (n 50). 
the conventional notion of 'socio-technical systems' in Science and Technology Studies (STS) has been unduly limited to the social and cultural construction and implications of particular technologies, without including their material, metabolic aspects in the definition of 'social'. In order to resume and refine the inter-disciplinary aspirations of historical materialism, as in Marx's discussion of machinery in Capital and Grundrisse, we need to realize that energy flows must be included in our understanding of society. In the nineteenth century, there was a mutual conceptual exchange between physics and economics. ${ }^{54}$ While Marxist political economy intuitively acknowledges labour-power as a kind of energy, ${ }^{55}$ early physicists conversely adopted the concept of 'work' from political economy. Such long-abandoned aspirations to merge our models of 'Nature' and 'Society' within a common theoretical framework urgently need to be resumed if we are to grasp the complex relations between climate change, energy policy, economic polarization, and financial crisis. To understand the global distributive aspects of energy technologies or 'sociotechnical systems' we must include the physical, metabolic prerequisites of societies in the very definition of society. This will help us reconceptualize energy technologies as thoroughly social instruments of environmental load displacement.

\section{CONCLUSIONS}

In this article I have argued that the global injustices of the Anthropocene - whether in terms of energy, climate or environment more generally - can only be made visible by applying truly interdisciplinary perspectives that combine insights into both nature and society, while keeping the two aspects analytically distinct and refraining from the urge to reduce the natural to the social or vice versa. This approach makes it possible to rethink the ontology of modern technologies as societal strategies for the displacement of work as well as environmental loads, inherently contingent on asymmetric global transfers of biophysical resources and an accelerating production of entropy in the form, for instance, of carbon dioxide emissions. I have also indicated how ontological assumptions that disturb conditions of modern affluence are being kept out of view of mainstream economists, engineers, and people in general. However, the structural or 'slow' 56 violence mystified by the lofty self-perceptions of liberal democracy is gradually revealing itself in the form of obscene and growing global inequalities, as well as the increasingly incontrovertible recognition that the affluent consumer society of the global North cannot possibly be globalized. Although the democracies of North America, Europe, and other wealthy parts of the world-system tend to take pride in their liberal virtues and respect for human rights, this selfcongratulatory image is difficult to reconcile with their actual role in global society. We all need to uphold a virtuous moral identity, but it is becoming increasingly difficult for socialists and liberals alike to digest the fact that their visions of a global welfare society are utopian, and that even those of us who are most intent on saving the planet count among its heaviest burdens.

54. P Mirowski, More Heat than Light: Economics as Social Physics, Physics as Nature's Economics (Cambridge University Press, New York, NY 1989).

55. P Burkett, Marxism and Ecological Economics: Toward a Red and Green Political Economy (Brill, Leiden 2005).

56. R Nixon, Slow Violence and the Environmentalism of the Poor (Harvard University Press, Cambridge, MA 2011). 